\title{
DEVELOPMENTAL REPRODUCTIVE EFFECTS OF EXPOSURE TO PHARMACEUTICAL STEROIDS IN THE AQUATIC ENVIRONMENT: STUDIES ON MOSQUITOFISH (GAMBUSIA AFFINIS AFFINIS),ROACH (RUTILUS RUTILUS) AND MEDAKA(ORYZIAS LATIPES)
}

\author{
Taisen Iguchi \\ Okazaki Institute for Integrative Bioscience, National Institute for Basic Biology, National Institutes of Natural \\ Sciences, 5-1 Higashiyama, Myodaiji, Okazaki, 444-8787, Japan., taisen@nibb.ac.jp \\ Yoshinao Katsu \\ Okazaki Institute for Integrative Bioscience, National Institute for Basic Biology, National Institutes of Natural \\ Sciences, 5-1 Higashiyama, Myodaiji, Okazaki, 444-8787, Japan. \\ Hiroshi Urushitani \\ Okazaki Institute for Integrative Bioscience, National Institute for Basic Biology, National Institutes of Natural \\ Sciences, 5-1 Higashiyama, Myodaiji, Okazaki, 444-8787, Japan.
}

Anke Lange

University of Exeter, School of Biosciences, Environmental and Molecular Fish Biology Group, Exeter, Devon, EX4 4PS, United Kingdom.

Charles R. Tyler

University of Exeter, School of Biosciences, Environmental and Molecular Fish Biology Group, Exeter, Devon, EX4 4PS, United Kingdom.

Follow this and additional works at: https://jmstt.ntou.edu.tw/journal

Part of the Aquaculture and Fisheries Commons

\footnotetext{
Recommended Citation

Iguchi, Taisen; Katsu, Yoshinao; Urushitani, Hiroshi; Lange, Anke; and Tyler, Charles R. (2007) "DEVELOPMENTAL REPRODUCTIVE EFFECTS OF EXPOSURE TO PHARMACEUTICAL STEROIDS IN THE AQUATIC ENVIRONMENT: STUDIES ON MOSQUITOFISH (GAMBUSIA AFFINIS AFFINIS),ROACH (RUTILUS RUTILUS) AND MEDAKA(ORYZIAS LATIPES)," Journal of Marine Science and Technology. Vol. 15: Iss. 5, Article 4.

DOI: $10.51400 / 2709-6998.2056$

Available at: https://jmstt.ntou.edu.tw/journal/vol15/iss5/4

This Research Article is brought to you for free and open access by Journal of Marine Science and Technology. It has been accepted for inclusion in Journal of Marine Science and Technology by an authorized editor of Journal of Marine Science and Technology.
} 
DEVELOPMENTAL REPRODUCTIVE EFFECTS OF EXPOSURE TO

PHARMACEUTICAL STEROIDS IN THE AQUATIC ENVIRONMENT: STUDIES ON MOSQUITOFISH (GAMBUSIA AFFINIS AFFINIS),ROACH (RUTILUS RUTILUS) AND MEDAKA(ORYZIAS LATIPES)

\section{Acknowledgements}

This work was funded on grants from the Ministry of Environment, Japan, to YK and $\mathrm{TI}$, and from the UK Natural Environmental Research Council within the Environmental Genomics programme (NER/T/S/2002/ 00182) to CRT. 


\title{
DEVELOPMENTAL REPRODUCTIVE EFFECTS OF EXPOSURE TO PHARMACEUTICAL STEROIDS IN THE AQUATIC ENVIRONMENT: STUDIES ON MOSQUITOFISH (GAMBUSIA AFFINIS AFFINIS), ROACH (RUTILUS RUTILUS) AND MEDAKA (ORYZIAS LATIPES)
}

\author{
Taisen Iguchi*, Yoshinao Katsu*, Hiroshi Urushitani*, \\ Anke Lange** and Charles R. Tyler**
}

Key words: pharmaceutical steroids, aquatic environment, mosquitofish, roach, medaka.

\section{EFFECTS OF TRENBOLONE ON MOSQUITOFISH}

Contaminant-associated reproductive and developmental impacts have been reported in wildlife following exposure to endocrine disrupting environmental contaminants (EDCs) [7, 17, 67]. In vertebrates, EDCs affect hormone-dependent processes including sexual differentiation, development of secondary sex characteristics, ovulation, behavior and general homeostasis and they do so through various mechanisms $[9,45]$. In fish, estrogenic responses have been observed following exposure to pesticides [68], surfactants [69], pulp mill effluent [54], industrial waste water [25] and sewage effluent [22]. Androgenic substances have also been associated with disruptions in sexual development in fish and they include masculinization of mosquitofish (Gambusia affinis) living in rivers polluted with pulp mill effluent $[11,21,53,65]$. The androgenic effects reported include the development of a male-like gonopodium (the modified anal fin in males that acts as a copulatory organ), and altered reproductive behavior in females. These effects have been confirmed via laboratory exposure experiments $[3,13,53]$. Similarly induction of male secondary sex characteristics, such as male-like coloration have been induced in female guppy (Poecilia reticulata) exposed to pulp mill effluents [39]. These androgenic effects have been confirmed using various in vitro assays $[12,53]$ however, the substances and mechanisms producing androgenic action are largely unknown $[4,16]$.

Recently, studies in wild fathead minnows (Pimephales promelas) have shown the presence of potent androgenic substances in feedlot effluent discharged into rivers in the U.S.A. [51] and this finding
Author for Correspondence: Taisen Iguchi.

E-mail: taisen@nibb.ac.jp

* Okazaki Institute for Integrative Bioscience, National Institute for Basic Biology, National Institutes of Natural Sciences, 5-1 Higashiyama, Myodaiji, Okazaki, 444-8787, Japan.

**University of Exeter, School of Biosciences, Environmental and Molecular Fish Biology Group, Exeter, Devon, EX4 4PS, United Kingdom. 
has been confirmed using in vitro cell assays [63] and a transcriptional activation assay [51]. The androgenic activity contained in feedlot effluent has been identified as being derived from trenbolone, a growth-promoting hormone used for the production of approximately $90 \%$ of beef cattle in the United States [5]. Trenbolone, an approved androgenic, anabolic steroid is generally administered via an ear implant and induces rapid weight gain [5]. Trenbolone acetate, the implanted drug, is rapidly hydrolyzed to an active form, $17 \beta$-trenbolone (TB), which is epimerized to $17 \alpha$-trenbolone, a metabolite with significantly less biological action. TB and $17 \alpha$-trenbolone are both excreted by the treated animal [60]. TB acts as a potent agonist of mammalian androgen receptors (ARs), with a binding affinity to the human AR comparable to dihydrotestosterone (DHT), 20 -fold higher than for $17 \alpha$-trenbolone $[6,71]$. Moreover, TB induces AR-dependent gene transcription in vitro in a transfected cell line with a potency similar to DHT [5]. TB also binds to an AR of the fathead minnow, and with a greater affinity than for testosterone [4]. Exposure of adult female fathead minnows to TB $(\geq 0.027 \mu \mathrm{g} / \mathrm{L})$ has been shown to reduce fecundity, reduce concentrations of both plasma vitellogenin (VTG) and sex steroid and to induce masculinization of secondary sex characteristics, including male specific dorsal nuptial tubercles [4]. No effects on fry or juvenile fish have been reported at the concentrations tested to date.

Androgenic actions of environmental chemicals are likely to be directly correlated with interaction with and transcriptional regulation by ARs or synthesis of endogenous androgens. In order to further investigate the effects of TB on AR signaling, we cloned the AR genes $A R \alpha$ and $A R \beta$ from the western mosquitofish [62] and evaluated the effect of TB on sexual development and AR expression in the mosquitofish. Studies were undertaken on both adult fish and on fish during early life.

Comparison of the predicted amino acid sequences of the cloned mosquitofish (mo)AR $\alpha$ and moAR $\beta$ with other ARs showed eight completely conserved cysteine residues in two zinc finger motifs, and a P-box (GSCKV) in the DNA binding domain, which plays an important role in determining the target genes for interaction [66]. Moreover, a leucine zipper-like structure in the $\mathrm{COOH}$ terminal ligand binding domain, which is conserved in many nuclear receptors and required for dimerization of receptors [55], was also conserved in the moAR $\alpha$ and moAR $\beta$, as reported previously in ARs for other teleosts. Our phylogenetic analysis of the two forms of moAR suggests strong similarity with those reported in other teleosts.

TB was found to be a potent androgen in mosquitofish [62], as shown previously in the fathead minnow [4] and exposure to pharmacological concentrations of TB $(1 \mu \mathrm{g} / \mathrm{L})$ induced gonopodium differentiation from the anal fin of adult females [71]. This phenotype in female mosquitofish has been reported previously following exposure to other androgens [62]. Both types of moAR mRNA were expressed in all fins of androgen-treated female mosquitofish and therefore we cannot conclude which AR in the anal fin contributes to the differences in the response to TB among fins. It is possible that it is the modification of moAR gene expression in distinct regions of the anal fin that plays important roles during gonopodium formation. Exposure of mosquitofish fry to ethinyltestosterone (1.6-32 $\mathrm{nM}$ ) induced anal fin elongation at the distal tip of the fin 4 days after exposure was initiated [50]. Interestingly, we observed an increased expression of both moAR mRNAs during TB-induced gonopodium development as early as 3 days after initiating the exposure [62]. These findings suggest a positive feed-back loop of TB on AR gene expression, and presumably translation of the moAR mRNA is necessary during the earliest period of the androgen-dependent gonopodium differentiation. In addition to its mechanism of action via homodimerization, ARs also exhibit a role as a nuclear receptor and transcription factor by forming heterodimers with AP-1 [59], Smad3 [19, 26], NFKB [1, 52], SRY [72] or Ets [61]. Together with AR coregulators [20], expression levels of these factors would directly affect the androgenic action of TB with the moARs to induce gonopodium differentiation during the early response phase. Sonic hedgehog expression also is important in the developing gonopodium of mosquitofish following exposure to a pharmaceutical androgen [19]. Detailed studies examining the molecular mechanisms underlying gonopodium differentiation and development driven by androgens need to be performed to more fully appreciate the basic control processes.

In developing fry, one can not distinguish externally males from females until a gonopodium develops in males at about 70 days after birth, which culminates in a fully mature gonopodium around day 105 [3]. Following androgenic stimulation with TB at concentrations as low as $0.3 \mu \mathrm{g} \mathrm{TB} / \mathrm{L}$ in the water, formation and elongation of a gonopodium was observed in 28 days old fry [62].

Exposure to pharmacological concentrations (1.0 or $10.0 \mu \mathrm{g} / \mathrm{L}$ ) of TB induced premature differentiation of spermatozoa in the testes of 28-day-old male fry [62]. Spermatocyte differentiation and spermatozoa are normally not observed in the testis of mosquitofish until days 70 and 90, respectively [34]. In addition, spermatocytes and spermatozoa were observed in 28 day-old 'female' fry that contained oocytes in ovaries, follow- 
ing exposure to 1.0 or $10.0 \mu \mathrm{g} \mathrm{TB} / \mathrm{L}$. Following TB treatment for 28 days after hatch, we observed fry with well-developed ovaries containing ovarian follicles and spermatocyte-containing tubule-like structures. Thus, exposure to $\mathrm{TB}$ in this experiment was associated with the formation of an ovotestis [62]. In contrast with fry, adult females exposed to $10.0 \mu \mathrm{g} / \mathrm{L}$ TB for 28 days did not develop ovotestes [62]. These findings suggest both the existence of a critical period for ovotestes induction by androgenic chemicals in mosquitofish and that environmental androgens need to be considered further as possible causal agents in the formation of ovotestes in other species.

In summary for effects in mosquitofish, TB altered anal fin differentiation at $0.3-10.0 \mu \mathrm{g} / \mathrm{L}$ and induced spermatogenesis in ovaries at $1.0-10.0 \mu \mathrm{g} / \mathrm{L}$ when fry were exposed from birth for 28 days. These initial findings confirm that TB is androgenic, at pharmacological concentrations, as observed in fathead minnow [51, 63]. Furthermore, TB altered gene expression profiles for both of the cloned moARs in a very specific pattern, restricted to moAR mRNAs in the anal fin [62]. For the development of AR responses as potential biomarkers of environmental androgens, future studies need to examine the differential response in AR expression in the fins in response to natural endogenous androgens and following exposure to environmentally relevant concentrations of exogenous androgens. Ideally, other AR regulated genes need to be studied further to better elucidate the molecular pathways associated with gonopodial development. The extensive distribution of mosquitofish, as well as their survival and persistence in highly contaminated environments, make this species an interesting biological model for assessing the biological activity of (anti) androgens in a wide range of aquatic environments.

\section{EFFECTS OF ETHINYLESTRADIOL ON ROACH}

Extensive studies on wild populations of roach (Rutilus rutilus) in UK rivers have shown that exposure to estrogenic effluents from wastewater treatment works (WwTWs) cause altered sexual development, and reduced fertility [23, 24]. Controlled exposures with roach have established the association between the feminized responses and WwTW effluents $[42,57]$. The pharmaceutical estrogen $17 \alpha$-ethinylestradiol $\left(\mathrm{EE}_{2}\right)$, used in the contraceptive pill, contributes to the estrogenic activity of WwTWs effluents and has been measured in effluents at concentrations up to $62 \mathrm{ng} / \mathrm{L}[10$, 64]. $\mathrm{EE}_{2}$ is also present in surface waters up to $5 \mathrm{ng} / \mathrm{L}$ $[2,70]$. Laboratory exposures to $\mathrm{EE}_{2}$ have shown $\mathrm{EE}_{2}$ is highly potent, inducing feminization in males in various fish species and resulting and resulting in re- duced reproduction success $[37,48]$. Indeed, $\mathrm{EE}_{2}$ is arguably the environmental estrogen of greatest concern for its potential impacts in aquatic wildlife.

Biological effects of estrogens are principally mediated through estrogen receptors (ERs). There are at least two subtypes of ERs (ER $\alpha$ and ER $\beta$ ) mediating the diverse functions of estrogens, and these have been cloned in a variety of vertebrate species $[27,30]$. Despite the widespread feminization of wild fish as a consequence of chemical exposure, the mechanisms of sexual disruption and roles of the different ER subtypes in this process are not established. To understand the ER mediated pathway of sexual disruption in the roach, $\mathrm{ER} \alpha, \mathrm{ER} \beta$, aromatase brain type (cyp19b) and aromatase gonad type (cyp19a) genes were cloned, sequenced and characterized from roach (Katsu et al., unpublished). Aromatases play fundamental roles in the steroidogenic pathway mediating the conversion of androgen to estrogen and thus, altered expression/activity of aromatases can affect sexual development and function, depending on when the alterations are induced in the life of the fish (Lange et al., unpublished data). Sequence and phylogenetic analysis demonstrated that both roach (r)ERs showed highest homologies with the corresponding sequences of fathead minnow (Katsu et al., unpublished data). The overall identity of the two rER genes was relatively low, indicating that each rER protein is not an alternatively spliced isoform, but rather is generated from a distinct gene. The differential functions of $E R \alpha$ and ER $\beta$, however, have yet to be fully clarified. Similar to the ERs, aromatases cloned from roach showed the highest sequence identities with their orthologs isolated from other cyprinids. Whilst both aromatase isoforms showed a high percentage of sequence identity to their orthologs in other teleost species, the overall sequence identity between both roach aromatases was lower, indicating that they are only distantly related.

Exposure of roach during early life to an environmentally relevant concentration of $\mathrm{EE}_{2}(4 \mathrm{ng} / \mathrm{L})$ disrupted the normal dynamics of sexual development, inducing VTG and a concentration-related feminization of the gonadal ducts in male fish (Katsu et al., unpublished data), comparable with the effects seen in studies in zebrafish (Danio rerio) and fathead minnow for similar exposure regimes $[14,37]$. Concentration-related up-regulation of $\mathrm{rER} \alpha$ and $\mathrm{rER} \beta$ expression in both the body and head were associated with the altered sexual phenotype in the roach. In studies on fathead minnow and largemouth bass (Micropterus salmoides), the expression of ER $\beta$ was not found to be affected by administration of exogenous $17 \beta$-estradiol $\left(\mathrm{E}_{2}\right)$ [15, 58 , whereas in adult zebrafish, $\mathrm{E}_{2}$ resulted in a downregulation of hepatic expression of ER $\beta$ [46]. Consistently across all of these fish studies, ER $\alpha$ has been 
shown to be the most responsive ER gene to estrogenic stimulation. These data support the hypothesis that ER subtypes do not contribute equally to estrogen-dependent gene regulation, including for vitellogenesis [58]. Other studies have shown elevated gonadal ER expression after exposure of adult medaka and male zebrafish to $\mathrm{EE}_{2}[8,41]$. The induction of both rERs in heads of fish exposed to the lower concentrations of $\mathrm{EE}_{2}$ might reflect a positive feedback regulation of ER expression stimulated by the exogenous estrogen. The described feminizing effects of $\mathrm{EE}_{2}$ on developing roach were also associated with a concentration-related induction of the expression cyp19b in the heads and, to a lesser extend, the bodies of exposed roach, both with a marked increase at the highest concentration (our own unpublished data). This finding is in agreement with a previous studies in which developing or juvenile zebrafish were exposed to estradiol, xenoestrogens and $\mathrm{EE}_{2}$ which all resulted in elevated levels of brain-type cytochrome P450 aromatase mRNA [31, 32]. In contrast, a clear dose-response pattern was not seen for the expression of the gonad type aromatase in juvenile roach.

We also developed ER reporter gene assays for two roach and medaka ERs to investigate the ability of a range of environmental estrogenic chemicals to bind and activate ERs [29]. We used a reporter gene transcriptional assay using a GAL4 system with Chinese Hamster Ovarian K-1 (CHO-K1) cells and modified the two-hybrid system using mammalian cells that can be used to study protein-protein interactions, as has been described previously [28]. Estrogenic activities of various steroid hormones and chemicals were tested and as for the conventional ERE-luciferase reporter assay system, estrone $\left(E_{1}\right), E_{2}$, estriol $\left(E_{3}\right), E_{2}$, diethylstilbestrol (DES) all induced transcriptional activity via GAL4-ERs. We found that $\mathrm{E}_{2}$ induced luciferase activity by more than 100 -fold, which appears to be more suitable than the ERE-luciferase system for assays of ER-transactivation. Concentration-dependent stimulation of transcriptional activity was found at concentrations of $\mathrm{E}_{2}$ higher than $10^{-9} \mathrm{M}$ for both the roach and medaka ER assays, but the medaka (m)ER $\alpha$ responded to $\mathrm{EE}_{2}$ and DES at lower concentrations compared with $\mathrm{rER} \alpha$. These results indicate that the $\operatorname{mER} \alpha$ and $\mathrm{rER} \alpha$ may differ in their relative sensitivities to specific estrogens.

Estrogens induced concentration-dependent activation of both rERs. For the natural estrogens, transactivation was significantly induced in a sequence of effectiveness of $E_{2} \sim E_{1}>E_{3}$ for both rER subtypes, similar to the preferences of ERs isolated from rat and Atlantic croaker $[18,36] . \mathrm{EC}_{50}$ values indicated that $\mathrm{rER} \beta$ was more sensitive to steroidal estrogens compared with $\mathrm{rER} \alpha$. A higher sensitivity of zebrafish (zf)ER $\beta$ for $E_{2}$ (7-fold) and $\mathrm{EE}_{2}$ (10-fold) has been reported [64], but in contrast with the study on rERs, zfER $\alpha$ was slightly more sensitive to $E_{1}$ than $z f E R \beta$. Exposure of fish to alkylphenols induces feminizing responses $[33,56]$ and they are likely to be induced through the activation of ERs. OP and NP were shown to have a weak activation of $\mathrm{rER} \alpha$ only in the reporter gene assay.

In order to obtain a more detailed understanding of the gene pathways affected by estrogen exposure and how they relate to disruption of sexual differentiation and the induction of testis-ova in fish, 42 genes known to be involved in reproductive function of fish have now been cloned from roach. These genes include cDNAs encoding for steroid hormone receptors, steroidogenic enzymes, genes involved in sex differentiation and gonad development, growth and hormone activity and 3 control genes [38]. A macroarray has been developed and validated for use containing all 42 roach cDNAs. An exposure to $E_{2}$ in the laboratory over a 2 year period has been undertaken with roach and effects on gonadal gene expression and the associated gonadal phenotype are under investigation at various sampling life stages up to when the fish mature. In this work, using molecular responses (including ER and aromatase genes) we have identified that exposure to $\mathrm{EE}_{2}$ during early life may sensitize the responsiveness of roach to estrogen subsequently in later life. It is envisaged that this detailed work with lab-based exposures to $\mathrm{EE}_{2}$ and effluent will further unravel the mechanisms underlying sexual disruption in wild roach in UK rivers.

In summary for the work on roach, the differences in structure between $\mathrm{rER} \alpha$ and $\operatorname{ER} \beta$ and differences in their tissue expression imply distinct physiological functions. In mammals, ER $\alpha$ is critical for fertility in both sexes $[35,43]$ and ER $\beta$ appears to be the only ER found in germ cells, indicating a more fundamental role for ER $\beta$ in germ cell development/differentiation [49]. In roach, both $\operatorname{rER} \alpha$ and $\operatorname{rER} \beta$ have functional roles in the normal development of the gonad and brain in both sexes and both subtypes signal for ER-mediated disruption of sexual development. In addition to the ERs, P450 aromatases have also been established as targets for signaling disruption of sexual differentiation in roach. By altering the expression of aromatase genes, environmental estrogens, in this case $E_{2}$, affect the normal physiological ratio of androgens to estrogens. The resulting imbalance of steroids can lead to developmental and reproductive consequences [8]. The reporter gene assays developed showed that both rER subtypes can be activated by environmental estrogens and mediate disruptions in sexual development and function. However, the ER subtypes appear to differ in their sensitivities and responsiveness to different environmental estrogens, especially $\mathrm{EE}_{2}$. The present study 
adds substantial support to the hypothesis that $\mathrm{EE}_{2}$ plays a major role in disruption of sexual function in wild roach in UK rivers and the effects other environmental estrogens are signaled through both ER subtypes.

\section{EFFECTS OF ESTROGEN ON MEDAKA}

Japanese medaka has been widely used for the evaluation of the effects of chemicals (and estrogenic effluents from sewage treatment works) on sexual development and function, because of its short life cycle, ease of rearing and ability to distinguish sex by the secondary sex characteristics and the use of a genetic male marker, $D M Y$ [44]. In this species, in addition to the use of hepatically derived VTG induction and testisova formation in males as signals for estrogenic disruption, the morphology of dorsal and anal fins and formation of papillae have been used for assessing exposure to androgenic chemicals. Exposure of medaka from post-hatch to adulthood (for 70-100 days) to 24.5 $\mathrm{ng} \mathrm{EE}_{2} / \mathrm{L}$ has been shown to induce testis-ova in $80 \%$ of

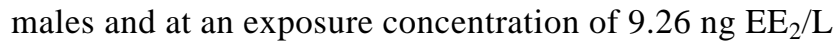
resulted in a lower fertility [47]. Our ongoing molecular work on the medaka is focused on identifying and cloning genes that might act as biomarkers of subsequent induction of testis-ova. To date, we have identified and cloned two genes specifically expressed in $\mathrm{EE}_{2}$-exposed testis in male medaka using a differential display method.

\section{CONCLUSIONS}

A variety of natural and man-made chemicals can mimic or inhibit hormonal activities by binding to hormone receptors and in turn this may modulate endocrine systems. This is especially true for aquatic species where exposure to such chemicals can be considerable and continuous. Hormonally active chemicals, especially pharmaceutical steroids that are the most potent, have been shown to cause disruption of sexual differentiation and development, and to impact on reproduction in various fish species. Studies on the effects of the pharmaceutical androgen TB on mosquitofish and the pharmaceutical estrogen $\mathrm{EE}_{2}$ on roach have shown that at some locations in the environment they appear to play key roles in inducing sexual disruption. To investigate the molecular mechanisms of these hormonal effects, we have cloned a series of genes including those coding for hormone receptors and genes involved in sex determination/differentiation. To date, analysis on ARs, ERs and aromatases have shown them to be effective targets for signaling disruption of sexual development/ function. The cloned ARs and ERs have been further applied to develop reporter gene assays to investigate the relative potencies of environmental endocrine disrupting chemicals and to identify species-related differences. Our work on $\mathrm{EE}_{2}$-exposed medaka has identified two genes which appear to be related to the induction of testis-ova and as such may be useful as biomarkers for testis-ova induction in fish in general. Our focused efforts are to increase the molecular toolbox for these fish species to investigate both the normal mechanisms controlling sexual development and how endocrine disrupting chemicals disrupt these processes.

\section{ACKNOWLEDGEMENTS}

This work was funded on grants from the Ministry of Environment, Japan, to YK and TI, and from the UK Natural Environmental Research Council within the Environmental Genomics programme (NER/T/S/2002/ 00182) to CRT.

\section{REFERENCES}

1. Aarnisalo, P., Palvimo, J.J., and Janne, O.A., "CREBBinding Protein in Androgen Receptor-Mediated Signaling," Proceedings of the National Academy of Sciences USA, Vol. 95, pp. 2122-2127 (1998).

2. Aherne, G.W. and Briggs, R.. "The Relevance of the Presence of Certain Synthetic Steroids in the Aquatic Environment," Journal of Pharmacy and Pharmacology, Vol. 41, pp. 735-736 (1989).

3. Angus, R.A., McNatt, H.B., Howell, W.M., "Gonopodium Development in Normal Male and 11ketotestosterone-Treated Female Mosquitofish (Gambusia affinis): A Quantitative Study using Computer Image Analysis," General and Comparative Endocrinology, Vol. 123, pp. 222-234 (2001).

4. Ankley, G.T., Jensen, K.M., Makynen, E.A., "Effects of the Androgenic Growth Promoter 17 $\beta$-Trenbolone on Fecundity and Reproductive Endocrinology of the Fathead Minnow," Environmental Toxicology and Chemistry, Vol. 22, pp. 1350-1360 (2003).

5. Balter, M., "Trade Policy - Scientific Cross-Claims Fly in Continuing Beef War," Science, Vol. 284, pp. 1453-+ (1999).

6. Bauer, E.R.S., Daxenberger, A., Petri, T., "Characterisation of the Affinity of Different Anabolics and Synthetic Hormones to the Human Androgen Receptor, Human Sex Hormone Binding Globulin and to the Bovine Progestin Receptor," Apmis, Vol. 108, pp. 838-846 (2000).

7. Colborn, T. and Clement, C., Chemically-Induced Alterations in Sexual and Functional Development: The Wildlife/Human Connection, Princeton Scientific Publishing, Princeton, p. 403 (1992).

8. Contractor, R.G., Foran, C.M., Li, S.F., "Evidence of 
Gender- and Tissue-Specific Promoter Methylation and the Potential for Ethinylestradiol-Induced Changes in Japanese Medaka (Oryzias latipes) Estrogen Receptor and Aromatase Genes," Journal of Toxicology and Environmental Health, Vol. 67, pp. 1-22 (2004).

9. Crain, D.A., Rooney, A.A., and Orlando, E.F., "Endocrine-Disrupting Contaminants and Hormone Dynamics: Lessons From Wildlife," In Guillette, L.J. and Crain, D. A. (Eds), Endocrine Disrupting Contaminants: An Evolutionary Perspective, Francis and Taylor Inc., Philadelphia, pp. 1-21 (2001).

10. Desbrow, C., Routledge, E.J., Brighty, G.C., "Identification of Estrogenic Chemicals in STW Effluent. 1. Chemical Fractionation and in vitro Biological Screening," Environmental Science \& Technology, Vol. 32, pp. 15491558 (1998).

11. Drysdale, D.T. and Bortone, S.A., "Laboratory Induction of Intersexuality in the Mosquitofish, Gambusia affinis, using Paper Mill Effluent," Bulletin of Environmental Contamination and Toxicology, Vol. 43, pp. 611617 (1989).

12. Durhan, E.J., Lambright, C., Wilson, V., "Evaluation of Androstenedione as an Androgenic Component of River Water Downstream of a Pulp and Paper Mill Effluent," Environmental Toxicology and Chemistry, Vol. 21, pp. 1973-1976 (2002).

13. Ellis, R.J., Van Den Heuvel, M.R., Bandelj, E., "In vivo and in vitro Assessment of the Androgenic Potential of a Pulp and Paper Mill Effluent," Environmental Toxicology and Chemistry, Vol. 22, pp. 1448-1456 (2003).

14. Fenske, M., Maack, G., Schäfers, C., "An Environmentally Relevant Concentration of Estrogen Induces Arrest of Male Gonad Development in Zebrafish, Danio rerio, "Environmental Toxicology and Chemistry, Vol. 24, pp. 1088-1098 (2005).

15. Filby, A.L. and Tyler, C.R., "Molecular Characterization of Estrogen Receptors 1, 2a and 2b and Their Tissue and Ontogenic Expression Profiles in Fathead Minnow (Pimephales promelas)," Biology of Reproduction, Vol. 73, pp. 648-662 (2005).

16. Gray, L.E., Ostby, J., Furr, J., "Effects of Environmental Antiandrogens on Reproductive Development in Experimental Animals," Human Reproduction Update, Vol. 7, pp. 248-264 (2001).

17. Guillette, L.J. and Gunderson, M.P., "Alterations in Development of Reproductive and Endocrine Systems of Wildlife Populations Exposed to Endocrine-Disrupting Contaminants," Reproduction, Vol. 122, pp. 857-864 (2001).

18. Hawkins, M.B., and Thomas, P., "The Unusual Binding Properties of the Third Distinct Teleost Estrogen Receptor Subtype ERßa are Accompanied by Highly Conserved Amino Acid Changes in the Ligand Binding
Domain," Endocrinology, Vol. 145, pp. 2968-2977 (2004).

19. Hayes, S.A., Zarnegar, M., Sharma, M., "SMAD3 Represses Androgen Receptor-Mediated Transcription," Cancer Research, Vol. 61, pp. 2112-2118 (2001).

20. Heinlein, C.A. and Chang, C.S., "Androgen Receptor (AR) Coregulators: An Overview," Endocrine Reviews, Vol. 23, pp. 175-200 (2002).

21. Howell, W.M., Black, D.A., and Bortone, S.A., "Abnormal Expression of Secondary Sex Characters in a Population of Mosquitofish, Gambusia affinis holbrooki Evidence for Environmentally-Induced Masculinization," Copeia, pp. 676-681 (1980).

22. Jobling, S. and Sumpter, J.P., "Detergent Components in Sewage Effluent are Weakly Estrogenic to Fish - an in Vitro Study using Rainbow Trout (Oncorhynchus mykiss) Hepatocytes," Aquatic Toxicology, Vol. 27, pp. 361-372 (1993) .

23. Jobling, S., Beresford, N., Nolan, M., "Altered Sexual Maturation and Gamete Production in Wild Roach (Rutilus rutilus) Living in Rivers That Receive Treated Sewage Effluents," Biology of Reproduction, Vol. 66, pp. 272-281 (2002).

24. Jobling, S., Coey, S., Whitmore, J.G., "Wild Intersex Roach (Rutilus rutilus) Have Reduced Fert-ility," Biology of Reproduction, Vol. 67, pp. 515-524 (2002).

25. Jobling, S., Reynolds, T., White, R., "A Variety of Environmentally Persistent Chemicals, Including Some Phthalate Plasticizers, are Weakly Estrogenic," Environmental Health Perspectives, Vol. 103, pp. 582-587 (1995).

26. Kang, H.Y., Lin, H.K., Hu, Y.C., "From Transforming Growth Factor-Beta Signaling to Androgen Action: Identification of Smad3 as an Androgen Receptor Coregulator in Prostate Cancer Cells," Proceedings of the National Academy of Sciences USA, Vol. 98, pp. 3018-3023 (2001).

27. Katsu, Y., Bermudez, D.S., Braun, E.L., "Molecular Cloning of the Estrogen and Progesterone Receptors of the American Alligator," General and Comparative Endocrinology, Vol. 136, pp. 122-133 (2004).

28. Katsu, Y., Kohno, S., Oka, T., "Molecular Cloning of Estrogen Receptor Alpha (ER $\alpha$; ESR1) of the Japanese Giant Salamander, Andrias japonicus," Molecular and Cellular Endocrinology, Vol. 257-258, pp. $84-94$ (2006).

29. Katsu, Y., Lange, A., Tyler, C.R., "Study of LigandSpecificity of Fish Estrogen Receptors," 8th UK-Japan Collaborative Research Meeting, Dartington, UK (2006).

30. Katsu, Y., Myburgh, J., Kohno, S., "Molecular Cloning of Estrogen Receptor $\alpha$ of the Nile Crocodile," Comparative Biochemistry and Physiology Part A: Molecular \& Integrative Physiology, Vol. 143, pp. 340346 (2006).

31. Kazeto, Y., Place, A.R., and Trant, J.M., "Effects of 
Endocrine Disrupting Chemicals on the Expression of CYP19 Genes in Zebrafish (Danio rerio) Juveniles," Aquatic Toxicology, Vol. 69, pp. 25-34 (2004).

32. Kishida, M., McLellan, M., Miranda, J.A., "Estrogen and Xenoestrogens Upregulate the Brain Aromatase Isoform (P450aromB) and Perturb Markers of Early Development in Zebrafish (Danio rerio)," Comparative Biochemistry and Physiology Part B: Biochemistry and Molecular Biology, Vol. 129, pp. 261-268 (2001).

33. Knörr, S. and Braunbeck, T., "Decline in Reproductive Success, Sex Reversal, and Developmental Alterations in Japanese Medaka (Oryzias latipes) After Continuous Exposure to Octylphenol," Ecotoxicology and Environmental Safety, Vol.51, pp. 187-196 (2002).

34. Koya, Y., Fujita, A., Niki, F., "Sex Differentiation and Pubertal Development of Gonads in the Viviparous Mosquitofish, Gambusia affinis,” Zoological Science, Vol. 20, pp.1231-1242 (2003).

35. Krege, J.H., Hodgin, J.B., Couse, J.F., "Generation and Reproductive Phenotypes of Mice Lacking Estrogen Receptor $\beta$," Proceedings of the National Academy of Sciences USA, Vol. 95, pp. 15677-15682 (1998).

36. Kuiper, G., Carlsson, B., Grandien, K., "Comparison of the Ligand Binding Specificity and Transcript Tissue Distribution of Estrogen Receptors $\alpha$ and $\beta$," Endocrinology, Vol. 138, pp. 863-870 (1997).

37. Länge, R., Hutchinson, T.H., Croudace, C.P., "Effects of the Synthetic Estrogen 17 $\alpha$-Ethinylestradiol on the LifeCycle of the Fathead Minnow (Pimephales promelas)," Environmental Toxicology and Chemistry, Vol. 20, pp. 1216-1227 (2001).

38. Lange, A., Katsu, Y., Iguchi, T., "Investigating the Molecular Mechanisms of Oestrogenic Disruption in the Roach, Rutilus rutilus," 8th UK-Japan Collaborative Research Meeting, Dartington, UK (2006).

39. Larsson, D.G.J., Kinnberg, K., Sturve, J., "Studies of Masculinization, Detoxification, and Oxidative Stress Responses in Guppies (Poecilia reticulata) Exposed to Effluent from a Pulp Mill," Ecotoxicology and Environmental Safety, Vol. 52, pp. 13-20 (2002).

40. Le Page, Y., Scholze, M., Kah, O., "Assessment of Xenoestrogens using Three Distinct Estrogen Receptors and the Zebrafish Brain Aromatase Gene in a Highly Responsive Glial Cell System," Environmental Health Perspectives, Vol. 114, pp. 752-758 (2006).

41. Legler, J., Broekhof, J.L.M., Brouwer, A., "A Novel in Vivo Bioassay for (Xeno-) Estrogens using Transgenic Zebrafish," Environmental Science \& Technology, Vol. 34 , pp. 4439-4444 (2000).

42. Liney, K.E., Jobling, S., Shears, J.A., "Assessing the Sensitivity of Different Life Stages for Sexual Disruption in Roach (Rutilus rutilus) Exposed to Effluents from Wastewater Treatment Works," Environmental Health Perspectives, Vol. 113, pp. 1299-1307 (2005).
43. Lubahn, D.B., Moyer, J.S., Golding, T.S., "Alteration of Reproductive Function But not Prenatal Sexual Development After Insertional Disruption of the Mouse Estrogen-Receptor Gene," Proceedings of the National Academy of Sciences USA, Vol. 90, pp. 11162-11166 (1993).

44. Matsuda, M., Nagahama, Y., Shinomiya, A., "DMY is a Y-specific DM-Domain Gene Required for Male Development in the Medaka Fish," Nature, Vol.417, pp. 559563 (2002).

45. McLachlan, J.A., "Environmental Signaling: What Embryos and Evolution Teach Us About Endocrine Disrupting Chemicals," Endocrine Reviews, Vol. 22, pp. 319-341 (2001).

46. Menuet, A., Le Page, Y., Torres, O., "Analysis of the Estrogen Regulation of the Zebrafish Estrogen Receptor (ER) Reveals Distinct Effects of ERalpha, ERbeta1 and ERbeta2," Journal of Molecular Endocrinology, Vol. 32, pp. 975-986 (2004).

47. Ministry of the Environment, Environmental Health and Safety Division, Endocrine Disruptors: http://www.env. go.jp/en/chemi/ed/approach/annex_7.pdf (2005).

48. Nash, J.P., Kime, D.E., Van der Ven, L.T.M., "LongTerm Exposure to Environmental Concentrations of the Pharmaceutical Ethynylestradiol Causes Reproductive Failure in Fish," Environmental Health Perspectives, Vol. 112, pp. 1725-1733 (2004).

49. O'Donnell, L., Robertson, K.M., Jones, M.E., "Estrogen and Spermatogenesis," Endocrine Reviews, Vol. 22, pp. 289-318 (2001).

50. Ogino, Y., Katoh, H., and Yamada, G., "Androgen Dependent Development of a Modified Anal Fin, Gonopodium, as a Model to Understand the Mechanism of Secondary Sexual Character Expression in Vertebrates," FEBS Letter, Vol. 575, pp. 119-126 (2004).

51. Orlando, E.F., Kolok, A.S., Binzcik, G.A., "EndocrineDisrupting Effects of Cattle Feedlot Effluent on an Aquatic Sentinel Species, the Fathead Minnow," Environmental Health Perspectives, Vol. 112, pp. 353358 (2004).

52. Palvimo, J.J., Reinikainen, P., Ikonen, T., "Mutual Transcriptional Interference between RelA and Androgen Receptor," Journal of Biological Chemistry, Vol. 271, pp. 24151-24156 (1996).

53. Parks, L.G., Lambright, C.S., Orlando, E.F., "Masculinization of Female Mosquitofish in Kraft Mill EffluentContaminated Fenholloway River Water is Associated with Androgen Receptor Agonist Activity," Toxicological Sciences, Vol. 62, pp. 257-267 (2001).

54. Pelissero, C., Bennetau, B., Babin, P., "The Estrogenic Activity of Certain Phytoestrogens in the Siberian Sturgeon Acipenser Baeri," The Journal of Steroid Biochemistry and Molecular Biology, Vol. 38, pp. 293-299 (1991).

55. Pfahl, M., "Nuclear Receptor/Ap-1 Interaction," Endocrine Reviews, Vol. 14, pp. 651-658 (1993). 
56. Pickford, K.A., Thomas-Jones, R.E., and Wheals, B., "Route of exposure affects the oestrogenic response of fish to 4-tert-nonylphenol," Aquatic Toxicology, Vol. 65, pp. 267-279 (2003).

57. Rodgers-Gray T.P., Jobling S, Kelly C, "Exposure of Juvenile Roach (Rutilus rutilus) to Treated Sewage Effluent Induces Dose-Dependent and Persistent Disruption in Gonadal Duct Development," Environmental Science \& Technology, Vol. 35, pp. 462-470 (2001).

58. Sabo-Attwood, T., Kroll, K.J., and Denslow, N.D., "Differential Expression of Largemouth Bass (Micropterus salmoides) Estrogen Receptor Isotypes Alpha, Beta, and Gamma by Estradiol," Molecular and Cellular Endocrinology, Vol. 218, pp. 107-118 (2004).

59. Sato, N., Sadar, M.D., Bruchovsky, N., "Androgenic Induction of Prostate-Specific Antigen Gene is Repressed by Protein-Protein Interaction between the Androgen Receptor and AP-1/c-jun in the Human Prostate Cancer Cell Line LNCaP," Journal of Biological Chemistry, Vol. 272, pp. 17485-17494 (1997).

60. Schiffer, B., Daxenberger, A., Meyer, K., "The Fate of Trenbolone Acetate and Melengestrol Acetate After Application as Growth Promoters in Cattle: Environmental Studies," Environmental Health Perspectives, Vol. 109, pp. 1145-1151 (2001).

61. Schneikert, J., Peterziel, H., Defossez, P.A., “Androgen Receptor-Ets Protein Interaction is a Novel Mechanism for Steroid Hormone-Mediated Down-Modulation of Matrix Metalloproteinase Expression," Journal of Biological Chemistry, Vol. 271, pp. 23907-23913 (1996).

62. Sone, K., Hinago, M., Itamoto, M., "Effects of an Androgenic Growth Promoter 17 $\beta$-Trenbolone on Masculinization of Mosquitofish (Gambusia affinis affinis)," General and Comparative Endocrinology, Vol. 143, pp. 151-160 (2005).

63. Soto, A.M., Calabro, J.M., Prechtl, N.V., "Androgenic and Estrogenic Activity in Water Bodies Receiving Cattle Feedlot Effluent in Eastern Nebraska, U.S.A. Environ," Health Perspectives, Vol. 112, pp. 346-352
(2004).

64. Ternes, T.A., Kreckel, P. and Mueller, J., "Behaviour and Occurrence of Estrogens in Municipal Sewage Treatment Plants - II. Aerobic Batch Experiments with Activated Sludge," The Science of the Total Environment, Vol. 225, pp. 91-99 (1999).

65. Toft, G., Baatrup, E., and Guillette, L.J., “Altered Social Behavior and Sexual Characteristics in Mosquitofish (Gambusia holbrooki) Living Downstream of a Paper Mill," Aquatic Toxicology, Vol. 70, pp. 213-222 (2004).

66. Umesono, K. and Evans, R.M., "Determinants of Target Gene Specificity for Steroid Thyroid-Hormone Receptors," Cell, Vol. 57, pp. 1139-1146 (1989).

67. Vos, J.G., Dybing, E., Greim, H.A., "Health Effects of Endocrine-Disrupting Chemicals on Wildlife, with Special Reference to the European Situation," Critical Reviews in Toxicology, Vol. 30, pp. 71-133 (2000).

68. Wester, P.W., "Histopathological Effects of Environmental Pollutants Beta-HCHand Methyl Mercury on Reproductive Organs in Freshwater Fish," Comparative Biochemistry and Physiology Part C: Pharmacology, Toxicology and Endocrinology, Vol. 100, pp. 237-239 (1991)

69. White, R., Jobling, S., Hoare, S.A., "Environmentally Persistent Alkylphenolic Compounds are Estro-genic, "Endocrinology, Vol. 135, pp. 175-182 (1994).

70. Williams, R.J., Johnson, A.C., Smith, J.J.L., "Steroid Estrogens Profiles Along River Stretches Arising from Sewage Treatment Works Discharges," Environmental Science \& Technology, Vol. 37, pp. 1744-1750 (2003).

71. Wilson, V.S., Lambright, C., Ostby, J., "In vitro and in vivo Effects of 17 $\beta$-Trenbolone: A Feedlot Effluent Contaminant," Toxicological Sciences, Vol. 70, pp. 202211 (2002).

72. Yuan, X., Lu, M.L., Li, T., "SRY Interacts with and Negatively Regulates Androgen Receptor Transcriptional Activity," Journal of Biological Chemistry, Vol. 276, pp. 46647-46654 (2001). 